\title{
Injury to Rectum with Open Wound into Cavity
}

National Cancer Institute

\section{Source}

National Cancer Institute. Injury to Rectum with Open Wound into Cavity. NCI Thesaurus.

Code C35240.

Trauma to the rectum associated with a break in the tissue that extends into the rectum. 